\title{
BurgeONING BAIGENT? : A CRITIQUE OF THE LAW COMMISSION'S ANALYSIS OF BAIGENT'S CASE
}

\author{
Melanie Smith*
}

Who is responsible when a Crown entity or State enterprise breaches an individual's rights under the New Zealand Bill of Rights Act 1990? Is the Crown or the breaching entity primarily liable, or both? The Law Commission investigated this question in relation to liability arising out of Baigent's case. In its report the Law Commission recommended significantly narrowing the Crown's liability to exclude State enterprises and Crown entities. This article investigates the Law Commission's reasoning and recommendations.

\section{INTRODUCTION}

After the decision in Simpson $v$ Attorney-General (Baigent's case) ${ }^{1}$ the Law Commission was asked to investigate Baigent's case and its effect on Crown liability. ${ }^{2}$ It recommended against reversing Baigent by legislation, but also recommended that primary Crown liability under the New Zealand Bill of Rights Act 1990 (BORA) be limited to the executive branch of the government.

In this article Part II provides a brief background to Baigent's case; Part III provides an outline of the Law Commission's proposal, and the gaps in liability that it leaves; Part IV discusses the reasons given by the Law Commission for its recommendations; and Part V investigates some of the legal and practical effects that the Law Commission's proposal would have, in relation to breaches of the BORA and the provision of remedies.

* This paper was submitted as part of the LLB(Hons) programme. It was awarded the Robert Orr McGechan Prize in 1997 for legal writing at VUW.

1 Simpson v Attorney-General (Baigent's case) [1994] 3 NZLR 667 (CA).

2 Crown Liability and Judicial Immunity: A Response to Baigent's Case and Harvey v Derrick New Zealand Law Commission Report no. 37 (Wellington, 1997). This article deals only with Chapter 3 (The Bill of Rights Act, Baigent's case and its Implications) and Chapter 4 (A Legislative Response?) of the report. 
The word "Crown" is used throughout the article. For the purposes of its report the Law Commission adopted the definition of Crown contained in section 2 of the Public Finance Act 1989:

"Crown" or "Her Majesty" -

(a) Means Her Majesty the Queen in right of New Zealand; and

(b) Includes all Ministers of the Crown and all departments; but

(c) Does not include -

(i) An Office of Parliament, ${ }^{3}$ or

(ii) A Crown entity; ${ }^{4}$ or

(iii) A State enterprise named in the First Schedule to the State-Owned Enterprises Act 1986.

The definition is a narrow one. The Crown means Ministers and all departments, a subset of the executive, but does not include the entities named in paragraph (c). However this definition of Crown is not decisive because the word "Crown" is not used in the BORA. Further this definition does not help resolve the issue of liability, which is a question of policy, not semantics. Nevertheless, the Law Commission's narrow definition of Crown is important as the Law Commission used this definition in defining the boundaries of Crown primary liability.

\section{BAIGENT'S CASE}

\section{A Background}

Baigent's case significantly expanded Crown liability for BORA breaches. ${ }^{5}$ This may be why the Law Commission was asked to look into possible effects of Baigent's case and to recommend a response if necessary. It is important to state clearly the Court of Appeal's characterisation of liability in Baigent. The facts of the case were as follows.

3 Section 2, "Office of Parliament" means The Parliamentary Commissioner for the Environment (and that Commissioner's office), the Office of the Ombudsmen, and the Audit Office (including the Audit Department).

4 A Crown entity means a body or statutory officer named in the Fourth Schedule to the Act. The Crown entities listed in the Fourth Schedule include the Commerce Commission, the CRIs, CHEs, the Human Rights Commission, NZQA, the Police Complaints Authority, and the Race Relations Conciliator.

5 See also G Palmer and M Palmer Bridled Power : New Zealand Government Under MMP (Oxford University Press, Auckland, 1997) 275-277 for a discussion of Baigent's case. 
The police believed that one Troy O'Brien was selling cannabis. They applied, bona fide, for a search warrant in respect of 16 London Road. Mr O'Brien did not live at 16 London Road; rather Mrs Baigent (since deceased) and her son lived at that address.

On arrival at the house it was made clear to the police by a neighbour and the son that they had the wrong house. The police also talked on the telephone to Mrs Baigent's daughter, a barrister, who told the police that the search was illegal and asked them to leave. The police searched the house anyway. Nothing incriminating was found.

The executors of Mrs Baigent's estate and her son brought proceedings, including a claim for monetary compensation arising out of the breach of the BORA. ${ }^{6}$ The Court of Appeal $^{7}$ decided that a cause of action based on the BORA lay against the Crown, as did a claim for monetary compensation where that was an appropriate remedy.

The Court of Appeal looked particularly at the long title of the BORA. The long title refers to the International Covenant on Civil and Political Rights (ICCPR) ${ }^{8}$ which requires that effective domestic remedies are available. The Court was also concerned that the rights should not be empty, ${ }^{9}$ or "toothless". ${ }^{10}$ The Court of Appeal found the Privy Council case of Maharaj ${ }^{11}$ highly persuasive. In that case the appellant sought and gained compensation under the Constitution of Trinidad and Tobago in a public law action, for a breach of a constitutional right. Unlike the BORA the Constitution of Trinidad and Tobago contains a remedies clause.

\section{B Characterisation of Baigent Liability}

The Court left open much of the detail of the nature of the liability recognised in Baigent. This means that the courts can define the boundaries in future cases. The Court did however, state three bases of the cause of action arising from a breach of the BORA:

1 It is an independent action against the Crown; ${ }^{12}$

2 It is an action in public law, not tort law in any form; ${ }^{13}$

\footnotetext{
6 Section 21, unreasonable search and seizure.

7 Gault J dissenting.

8 New Zealand ratified the ICCPR on 28 December 1978 and it entered into force in New Zealand on 28 March 1979. New Zealand ratified the Optional Protocol to the ICCPR on 26 May 1989 and it entered into force on 26 August 1989.

9 Baigent, above n 1, 693; Ashby v White (1703) 2 Ld Raym 938; 92 ER 126.

10 Baigent, above $\mathrm{n} 1,676$

11 Maharaj v Attorney-General of Trinidad and Tobago (No. 2) [1979] AC 385; [1978] 2 All ER 670 (PC).

12 Baigent, above n 1, 690, 718
} 
3 It is a strict liability action for contravention of fundamental human rights. ${ }^{14}$

Justice McKay stated: ${ }^{15}$

It is the Crown as the legal embodiment of the State, which is bound by the International Covenant to ensure an effective remedy for the violation of fundamental rights. Parliament has affirmed those rights in order to affirm $\mathrm{New}$ Zealand's commitment to the International Covenant ... by a statute. ... [W] here a right is infringed by a branch of government or a public functionary the remedy under the Act must be against the Crown.

There are two things to note in relation to the character of the liability. First, the Court characterised the liability as being in public law. Thus, the Crown cannot rely on the immunities in the Crown Proceedings Act 1950 which relate to actions in tort. ${ }^{16}$ Second, the action was stated as being directly against the Crown. This creates a potentially wide liability as the BORA, by section 3, applies to any entity exercising a public function pursuant to law. ${ }^{17}$ For example, the Crown could be sued for compensation in relation to a breach of the BORA by a board of trustees, or a private company exercising a public function, ${ }^{18}$ without recourse to the board of trustees or the private company being necessary.

The broadening of Crown liability in Baigent's case ${ }^{19}$ in conjunction with section 3 , the application section of the BORA, highlights a policy question. What interest does the Crown have in actions where a breach of the BORA is pleaded ${ }^{20}$ And who should be

13 Baigent, above $\mathrm{n} 1,677,718$

14 Baigent, above $\mathrm{n} 1,700$. This characterisation as strict liability is accepted by the Law Commission, above n 2, para 91.

15 Baigent, above n 1, 718. Note that Justice McKay uses "Crown" in a much wider sense than the Law Commission definition.

16 Crown Proceedings Act 1950, s 6(5). The Court of Appeal has been criticised by some commentators for finding that a cause of action was available despite the immunities in the Crown Proceedings Act. See J Allan "Speaking with the Tongues of Angels: The Bill of Rights Act, Simpson and the Court of Appeal" [1994] BRB 2, as opposed to J Dawson "Simpson Liability" [1994] BRB 8.

17 See Bridled Power, above n 5, 264-265, 275.

18 TV3 Network Ltd v Eveready New Zealand Ltd [1993] 3 NZLR 435 (CA). This case involved a private entity exercising a public function. The Crown was not involved in the case.

19 The relevant cases which have considered s 3 in relation to Baigent liability are: Hobson v Harding (1995) 1 HRNZ 342 (HC); Innes v Wong [1996] 3 NZLR 238, (1996) 2 HRNZ 618 (HC) (striking out application); Unreported, 30 July 1996, High Court, Auckland, CP152/95 (application to withdraw CHE as a party); Rawlinson v Rice [1997] 2 NZLR 651.

20 For the Crown's lawyers' view see Hobson v Harding, above n 19. 
liable for a breach of the BORA? It is this latter question that the Law Commission was asked to investigate. ${ }^{21}$

\section{THE LAW COMMISSION'S RESPONSE TO BAIGENT}

\section{A Limiting Crown Liability by Section 3 of the Bill of Rights Act}

The Law Commission was asked to advise the government what legislative response, if any, should be made to Baigent's case. The Law Commission's response was that the reasoning in Baigent's case was correct, and that a monetary remedy should be available in situations where there is a breach of the BORA, and where no other remedy is appropriate. Thus the Law Commission recommended that no legislation be introduced to remove the remedy for a breach of the BORA that Baigent held to be available. The Law Commission stated that although a remedy should be available, it did not have to come from the Crown.

The Law Commission's proposal limited Crown liability on the basis of section $3:^{22}$

\section{APPLICATION -}

This Bill of Rights applies only to acts done -

(a) By the legislature, executive, or judicial branches of the government of New Zealand; or

(b) By any person or body in the performance of any public function, power, or duty conferred or imposed on that person or body by or pursuant to law.

The Law Commission recommended that the Crown remain primarily liable under section 3(a) for Crown acts, ${ }^{23}$ under the narrow definition of "Crown" in the Public Finance Act 1989.24 In terms of primary liability the Law Commission redefined the applicability of the BORA. It defined the Crown as all Ministers and departments, (a subset of section 3(a)) and then stated that primary liability would lie against the Crown only as so defined. In all other situations where the BORA applies, an action must be brought against the entity concerned if that is possible. In such situations the Crown has nothing to do with the action.

21 "In September 1995, as part of the Government's consideration of issues raised by Baigent's case, the Minister of Justice asked the Law Commission to give priority to its review of the Crown Proceedings Act 1950, and to include within that review a discussion of issues relating to Crown liability under the New Zealand Bill of Rights Act 1990." Law Commission, above n 2, ix.

22 For a commentary on s 3 and some discussion of the case law see P Radich and R Best "Section 3 of the Bill of Rights" [1997] NZLJ 251.

23 Law Commission, above n 2, para 108.

24 Law Commission, above n 2, paras 5, 94. 
The Law Commission is not suggesting that no-one is liable. It is rather a question of who bears liability for a breach of the BORA. The entities caught by section 3(b) would still be liable for monetary compensation under the BORA, but the liability would be with the entity concerned and not the Crown. ${ }^{25}$ For example, if a State Owned Enterprise $(\mathrm{SOE})^{26}$ breached the BORA such that Baigent liability arose, the plaintiff would bring an action against the SOE, which would be primarily liable. ${ }^{27}$ The Crown would be a party to the proceedings only if it was also a party to the relevant conduct. ${ }^{28}$

The Law Commission added that where there is no effective remedy available against a public entity, it is possible that the Crown might assume residual liability to ensure that a plaintiff is not left without an effective remedy. At paragraph 102 the Law Commission stated:

We have revisited our original total rejection of Crown residual liability and invite the Government to give further consideration to [the proposal that] ... the Crown should assume a residual liability where there would otherwise be no effective remedy.

This residual liability would be used in situations where, for example, a board of trustees breached the BORA but did not have the money to pay compensation. The Law Commission drafted a provision to be added to the BORA if residual Crown liability were considered desirable: ${ }^{29}$

If a person or body (not being the Crown) found liable under section 3(b) for a breach of this Act is unable to make redress, the Court may direct provision of redress by the Crown in such manner as the Court may think just.

It is difficult to understand the initial rejection of residual liability and the subsequent resistance to accepting it given the arguments the Law Commission sets out for retaining residual liability. The Law Commission stated that it may be argued that it is the State which is ultimately responsible for the whole system of Government. Given the obligations in article 2(3) of the ICCPR, the State should have both the incentive and the opportunity to ensure that the BORA is effective. ${ }^{30}$ Further the Law Commission noted

25 Law Commission, above n 2, paras 57, 86, 108.

26 The state enterprises are named in the First Schedule to the State Owned Enterprises Act 1986. They are presumably caught by s 3(b), see New Zealand Post in Federated Farmers of New Zealand Inc $v$ New Zealand Post Ltd [1990-92] 3 NZBORR 339 (HC).

27 See also discussion on Electricorp in Mercury Energy Ltd v Electricity Corporation of New Zealand Ltd [1994] 2 NZLR 385 (PC).

28 Law Commission, above n 2, paras 108, 109.

29 Law Commission, above n 2, para 105.

30 Law Commission, above n 2, para 102. 
that any gap in the system of protection is likely to entail a breach by New Zealand of its international responsibilities.

Residual liability would provide "a sanction for breach, a remedy to the person affected, and evidence that the rights are taken seriously within New Zealand institutions". ${ }^{31}$ It is stated that costs would be substantially contained if the Crown's liability was residual only in section $3\left(\right.$ b) cases. $^{32}$ Nevertheless, the Law Commission believed that the issue of Crown residual liability was "finely balanced". ${ }^{33}$

The argument opposing residual liability was that the taxpayer should not have to assume responsibility for conduct to which the Crown did not contribute. ${ }^{34}$ This theme of a requirement of contributory conduct by the Crown recurs as one of the bases on which the Law Commission justified limiting Crown liability to "Crown" entities.

Given that the purpose of the BORA is to provide a check on the power of the State (as well as to fulfil New Zealand's international obligations) it is prudent to apply a rigorous analysis to any proposals by the Crown to cut back the effectiveness of BORA measures.

\section{B The Effects of the Law Commission's Distinction}

The Law Commission's definition of the Crown gives a narrow construction to section 3(a). This leads to various consequences. The most obvious is that there are elements in section 3(a) that are not included in the definition of Crown - namely the legislature, the judiciary and parts of the executive that are not Ministers and departments. The Crown is not primarily liable for breaches by these entities and they are not covered by the proposed residual liability provision which applies only to section 3(b) entities. Where does this leave those entities that fall within the rest of section 3(a) in relation to the BORA?

\section{The Legislature}

If the Crown is not primarily liable for the legislature a plaintiff would have to sue the legislature itself, although it cannot be made a party to proceedings. Therefore no acts of the legislature can be challenged if an action cannot be brought against the Crown. This may not seem significant as section 4 of the BORA means that the ultimate legislative act, a statute, cannot be challenged. However, there are other acts of the legislature. As

\footnotetext{
31 Law Commission, above n 2, para 103.

32 Law Commission, above n 2, para 104.

33 Law Commission, above n 2, para 106.

34 Law Commission, above n 2, para 106.
} 
noted by Rodney Harrison, ${ }^{35}$ Parliamentary Select Committees, Parliament itself, or its Privileges Committee may deal with individuals. These entities have the power to impose a fine or imprisonment for a breach of privilege or a contempt of Parliament. The imposing of any of these sanctions could breach the BORA, but by the Law Commission's recommendation would cease to be subject to the BORA. This would have the effect of leaving these breaches without a remedy. It is important to note that this may also have the effect of removing the BORA as a ground of challenge of regulations.

\section{The Judiciary}

The Law Commission proposed that legislation be introduced stating that a remedy not be available against the Crown ${ }^{36}$ if an individual judge, ${ }^{37}$ or the courts, ${ }^{38}$ breach rights protected under the BORA. The Law Commission also recommended that the personal immunity of High Court Judges be extended to include District Court Judges. Thus an action could not be brought against the Crown or against a judge personally. The Law Commission recognised that this creates a gap in the law in relation to BORA breaches by the judiciary. ${ }^{39}$ It recommended withdrawing the reservation of, and enacting legislation to give effect to, ${ }^{40}$ article $14(6)$ of the ICCPR. Article 14(6) states that individuals who are subject to a miscarriage of justice at the hands of the judiciary should be compensated:

When a person has by a final decision been convicted of a criminal offence and when subsequently his conviction has been reversed or he has been pardoned on the ground that a new or newly discovered fact shows conclusively that there has been a miscarriage of justice, the person who has suffered punishment as a result of such conviction shall be compensated according to law, unless it is proved that the non-disclosure of the unknown fact in time is wholly or partly attributable to him.

35 G Huscroft and P Rishworth (eds) Rights and Freedoms (Brookers, Wellington, 1995) 435; see also P Joseph Constitutional and Administrative Law in New Zealand (The Law Book Company, Sydney, 1993) 853.

36 Law Commission, above n 2, para 186.

37 As in Maharaj, above n 11, and Harvey v Derrick [1995] 1 NZLR 314 (CA). See also Joe v Police Unreported, 21 December 1995, High Court, Wellington, AP 230/95, 12; The Queen v P Unreported, 17 November 1992, High Court, Auckland, T129/92.

Martin v Tauranga District Court [1995] 2 NZLR 419 (CA).

39 Law Commission, above n 2, para 180.

40 The judicial overturning of a conviction is a prerequisite to eligibility for the remedy, Law Commission, above $\mathrm{n} 2$, paras 162-164. 
The Law Commission noted that under the English legislation which gives effect to this article, the Secretary of State determines whether there is a right to such compensation after the judiciary has overturned a conviction. ${ }^{41}$ Even the enactment of similar legislation in New Zealand would only partially fill the gap. Article 14(6) relates only to criminal convictions. The judiciary acts in many ways which are not in the criminal sphere which have the potential to affect BORA rights. These situations would not be covered by the BORA under the Law Commission's recommendation, and breaches would be left without a remedy.

\section{The Executive}

There may be Crown officers and entities who could be considered part of the executive but do not fall within "all Ministers and Government departments". If these came before a court it is likely that a court would construe such entities as falling within section 3(b), that is performing a public function, and therefore an action could be brought against that entity. The Crown would not however be liable.

In conclusion it is clear that under the Law Commission recommendations:

1 The Crown is primarily liable for acts of the Governor-General, and all Ministers and departments - part of section 3(a) BORA.

2 Section 3(b) entities are themselves primarily liable.

3 The Crown may have residual liability for section $3(b)$ entities when the entity cannot pay.

4 This leaves some gaps in BORA coverage for other section 3(a) entities for which the Crown is not primarily or residually liable.

\section{THE LAW COMMISSION'S ARGUMENTS FOR THE PROPOSED LIMITATION}

The Law Commission made several arguments ${ }^{42}$ to justify its proposal that liability should be split between subsections (a) and (b) of section 3 of the BORA, and that liability for a public entity breach most appropriately lies with that entity alone.

\section{A Baigent's Case Concerned Police/Executive Action}

The Law Commission set out two alternative interpretations of Baigent. The Law Commission accepted that Baigent can be interpreted as indicating that any breach of the BORA gives rise to an action against the Crown, regardless of Crown culpability or

41 Law Commission, above n 2, paras 181-183.

42 Law Commission, above n 2, paras 86-92. 
responsibility for the action leading to the breach. In this way the Crown would be a total guarantor of the BORA. ${ }^{43}$ The statement by Justice McKay in Baigent supports this reading: "where a right is infringed by a branch of Government or a public functionary the remedy under the Act must be against the Crown". ${ }^{44}$

The second interpretation is narrower, and restricts Baigent to its particular facts. It interprets the Court of Appeal decision as to finding that the Crown could be directly liable for breaches of the BORA by the police. Baigent only imposed direct liability on the Crown for breaches by entities falling within the narrow interpretation of section 3(a). The Law Commission favoured this interpretation of Baigent. ${ }^{45}$

Given the wording and tone of the judgment it is strange to say that Baigent was a judgment confined to the police. The Judges must have been aware that they were fashioning a new cause of action that would be based on the precedent of their decision. The discussion is at a broad, principled level. In relation to fashioning a remedy for a breach of the BORA, Gault J said: ${ }^{46}$

It is important on such a major question of principle not to be distracted by the circumstances

of one particular case. The matter is to be approached broadly.

There is no particular reliance by the Court of Appeal on section 3(a). All five Judges noted section 3 and considered the applicability of the BORA. ${ }^{47}$ All Judges stated that the BORA applies only to the three branches of government and to the performance of public functions, powers or duties ${ }^{48}$ following the words of section 3 . There is no differentiation between section 3(a) and (b). They are, in fact, expressly mentioned together, and liability is attached in that context. ${ }^{49}$

After the initial statement of the facts in the majority judgments there is no reference back to the action being police action. If it was significant or crucial to the decision that the breach was by the police, the judgment could have been expected to state this.

The Law Commission's preference for a narrow interpretation of Baigent is not based on the view that it is the correct interpretation of the reasoning of the case. The Law

43 Law Commission, above n 2, para 94.

44 Baigent, above n 1, 718.

45 Law Commission, above n 2, paras 13, 86, 90, 94-95.

46 Baigent, above n 1, 709.

47 Baigent, above n 1, 676 as per Cooke P; 691, Casey J; 693, Hardie Boys J; 704, Gault J; 718, McKay J.

48 As per Hardie Boys J.

49 Baigent, above n 1, 691 as per Casey J. 
Commission admitted that in imposing Crown liability for the police breach the "members of the court did not expressly rely ... on the statement in s 3(a) that the Act binds acts of the three branches of government". ${ }^{50}$ The reasons given for preferring the second interpretation go instead to the nature of Baigent liability itself. The Law Commission rejected the broad reading of the liability in Baigent's case with the statement "we do not consider that such a broad principle of Crown residual liability can be justified". 51 It is clear that the Law Commission sought to counter any suggestion of the State as total guarantor.

The Law Commission maintained that Baigent is open to being interpreted as imposing liability only under section $3(\mathrm{a}) .{ }^{52}$ It is submitted that the Law Commission applied a strained interpretation of Baigent in order to limit Crown liability. It was open to the Law Commission to find that Baigent's case prescribed a liability that was inappropriately wide, and as such required legislative limitation: for example, by adding a provision to the BORA stating when the Crown is primarily liable and when the Crown has no liability. Such an approach would have been more transparent and would have retained the integrity of the Baigent decision. Any such proposed change to the BORA would ensure that the policy basis of the provision would be debated. While the Law Commission did draft a legislative provision it is based on the assumption that only the breaching entity is liable in section 3(b) situations. This is the very policy question that needs to be discussed. The Law Commission's draft provision would have the effect of letting its answer in through the back door.

\section{B Imposing Liability Strengthens Incentives to Comply}

One of the reasons given by the Law Commission was that imposing liability would strengthen incentives for public bodies to comply with the Act. ${ }^{53}$ This is, in essence, an argument based on practicalities, and is not an argument that addresses the principled basis of Baigent liability.

Deterrence is not the purpose of Baigent liability. The majority Judges agreed that the primary purpose is to affirm, acknowledge and give content and effect to the rights in the BORA. The President noted the ability of an award to deter further breaches ${ }^{54}$ but it was mentioned as one of several considerations to be taken into account when assessing

\footnotetext{
50 Law Commission, above n 2, para 86

51 Law Commission, above n 2, para 95.

52 Law Commission, above n 2, para 95.

53 Law Commission, above n 2, para 88.

54 Baigent, above n 1, 678 .
} 
quantum. Justice Hardie Boys stated that the emphasis should be on the compensatory and not the punitive element. ${ }^{55}$ The object of the remedy is to affirm the right, not to punish the transgressor or to deter potential future breaches. Strengthening incentives to comply is simply deterrence phrased differently. The Law Commission was saying that imposition of primary liability will have a deterrent effect on public bodies. This is not the purpose of Baigent damages.

Nevertheless, this is undoubtedly a valuable practical effect of Baigent liability. If it was decided on principle that Baigent liability should be primarily with the Crown there is nothing to prevent the Crown setting up internal mechanisms that produce financial consequences for entities that breach the BORA. A citizen would have an action against the Crown as guarantor, and it would be the Crown's responsibility to impose that "fine" on the entity concerned. This would still produce the desired deterrent effect, but would mean that the Crown, which is the most appropriate defendant, would be a principal party. Thus, while imposing liability would strengthen incentives to comply, these incentives could be provided regardless of whether it is the Crown or the entity which is primarily liable.

\section{Requirement of Crown Contributory Conduct}

It is a theme of the Baigent chapter of the Law Commission report that the Crown should not be liable for conduct to which it did not contribute. ${ }^{56}$ This is a position substantially similar to the dissent in Maharaj. ${ }^{57}$

The Law Commission accepted that Baigent liability is strict, or "no fault" liability ${ }^{58}$ as held in the Baigent decision and subsequent High Court decisions. ${ }^{59}$ An innocent breach is still a BORA breach, and attracts liability. For primary liability the Law Commission added a requirement that the Crown act in a contributory way. This requirement misses the point of Baigent liability.

Given the unique power and role of the State, the normal rule applying to individual citizens, that contributory conduct is required to impose liability, should not apply. ${ }^{60}$

60 For a different view see JA Smillie "The Allure of 'Rights Talk': Baigent's Case in the Court of Appeal" (1994) 8 Otago Law Review 188, 198-204.
} 
Fault, or some negligent conduct is required in order to impose a sanction on an individual, in order to protect that individual against arbitrary and unjust actions by officers of the State, or others within the community. Yet the State is not a private individual. The State is a powerful entity unlike any other in society. Fundamentally the BORA is a curb on the "formidable" power of the State. ${ }^{61}$ Even after the introduction of MMP, New Zealand's unicameral Parliament has supreme law-making power with very few fetters. ${ }^{62}$ The State exercises many public functions which affect individuals' lives. ${ }^{63}$ It does this by means of public agents, such as the police, the courts, separate public entities.

By claiming that contributory conduct is required, the State would be trying to take advantage of the legal benefits that individual citizens enjoy. The role of the State is to protect the rights of its citizens, not to seek its own protection to the detriment of those citizens.

Additionally, it is untenable to state that conduct by Crown entities is not attributable to the Crown. Crown entities, although legally separate from the Crown, are Crown creations with a public purpose. The Law Commission is able to plead that there is no contributory conduct by defining the Crown narrowly. If the Crown has taken responsibility for ensuring that there is an effective remedy for any breaches, then no contributory conduct by the Crown is needed.

Even the SOEs, which, of the Crown entities are the most independent of the Crown, cannot escape the public nature of the services they provide. In the case of Mercury Energy Ltd $v$ Electricity Corporation of New Zealand Ltd ${ }^{64}$ the Privy Council had to decide whether the decisions of ECNZ, an SOE, were amenable to judicial review. The relevant decision was to terminate a commercial contract. The Privy Council held that in principle the decisions of ECNZ were amenable to judicial review because ECNZ was a public body: 65

A state owned enterprise is a public body; its shares are held by Ministers who are responsible to the House of Representatives and accountable to the electorate, the Corporation carries on its business in the interests of the public, decisions made in the public interest by the Corporation,

61 M Chen and G Palmer Public Law in New Zealand (Oxford University Press, Auckland, 1993) 446.

62 G Palmer Unbridled Power (2ed, Oxford University Press, Auckland, 1987), see also Bridled Power, above $n$.

63 Above $n$ 61, 445.

64 Above $\mathrm{n} 27$.

65 Mercury Energy above n 27, 388. 
a body established by statute, may adversely affect the rights and liabilities of private individuals without affording them redress.

Judicial review was held to be not available to Mercury Energy on the facts of the case. ${ }^{66}$ Although not a BORA case Mercury Energy is the leading statement at present on the legal character of SOEs in New Zealand. Changing the form of SOEs to that of a limited liability company is not enough to remove them from the public sphere. The form may have changed but the public function remains the same. ${ }^{67}$ This functional test accords with international precedent. ${ }^{68}$

In terms of the BORA all that must be established is whether a Crown entity, falling within section 3 has breached a BORA right. Once a breach is established the question becomes how best to remedy the breach. This is entirely consistent with the approach to human rights at international law, and the practice of international human rights tribunals. The Human Rights Committee ${ }^{69}$ has jurisdiction to hear allegations of human rights breaches from individuals within a State's territory or subject to a State's jurisdiction. ${ }^{70}$ The Committee has recognised the ICCPR's third party applicability in relation to some articles of the Covenant in its General Comments on those articles. ${ }^{71}$ New Zealand has undertaken to ensure that the ICCPR rights are enforced and effective within New Zealand. ${ }^{72}$ Similarly, under the European Human Rights Convention the

66 Their Lordships put a gloss on the general principle when an SOE was determining a commercial contract. In those cases it was held that such a decision would almost never be the subject of judicial review in the absence of fraud, corruption or bad faith. Those requirements were not satisfied in the case.

67 A Shaw "Drug Testing in the Workplace and the Bill of Rights" [1995] New Zealand Law Review 22.

68 Cases interpreting "other authorities" or similar words in a definition of the State: Son Prakesh Rekhi v Union of India (1981) 1 SCC 449; Ajay Hasin v K M Sehravardi (1981) 2 SCC 66; Gunaratne v People's Bank [1987] LRC (Const) 383; and in New Zealand Commissioner of Inland Revenue v Medical Council of New Zealand (1997) 18 NZTC 13,088, 13,108.

69 The Human Rights Committee is the supervisory body established under the ICCPR (Part IV, arts 28-45). The Committee sits at the United Nations Office at Geneva, Switzerland.

70 For example in Martins v Uruguay (case no. 57/1979, HRC 1982 Report) the author of the communication, while living abroad, requested the renewal of her passport. She was held to be "subject to the jurisdiction" of Uruguay per A de Zayas, J Moller, T Opsahl "Application by the Human Rights Committee of the International Covenant on Civil and Political Rights Under the Optional Protocol" (1986) Canadian Human Rights Yearbook 101, 113.

71 For example, art 7, right to be free from torture, and cruel and degrading treatment.

72 Justice Cartwright, in Innes $v$ Wong, above n 19, recognises that the State's human rights responsibilities are wider than the BORA, and extend to all persons within New Zealand's territory. She states, at p242, that: "both of those [causes of action relating to public law remedies] 
contracting parties agree to secure the rights and freedoms in the Convention to "everyone within their jurisdiction". ${ }^{73}$ There is no requirement of State conduct or Crown involvement.

This third party applicability is a recognition by the international community of the fundamental nature of the rights, that redress is more important than attributing blame and is also a recognition of the special duties and obligations of States. Because of their power and access to resources they are in a position to address structures which may allow for human rights abuses. They are also the body most able to provide for systems that prevent human rights abuses in any particular territory, and have the resources to provide redress.

\section{Other Factors / Fault Requirement}

Despite expressly stating that Baigent liability is "strict" liability ${ }^{74}$ the Law Commission introduced an additional element of fault when considering remedies. Particular rights may require an element of fault to establish a breach, such as section 21, the right to be secure against "unreasonable" search and seizure, or section 22, the right not to be "arbitrarily" arrested or detained. Apart from these substantive requirements there is no generic fault requirement when damages are claimed for a BORA breach.

The Law Commission's recommendation was that the Crown entity itself would be primarily liable. ${ }^{75}$ The State would also be primarily liable to the extent that its contributory conduct meant that it should be liable. ${ }^{76}$ It was for the courts to decide whether the State's conduct was such as to render it primarily liable. ${ }^{77}$ The Law Commission then listed relevant factors that a court could take into account when deciding whether the Crown's conduct should render it liable. These factors were:

1 The nature and extent of the Crown's powers of supervision and control over the relevant public body; ${ }^{78}$

are based on allegations that the State has certain responsibilities whether under the New Zealand Bill of Rights Act or generally, to protect Matthew [Innes] from abuses of basic human rights. These are responsibilities which are placed on a State to ensure that its agents or nationals do not perpetuate or condone human rights abuses". Emphasis added.

73 Article 1.

74 Law Commission, above n 2, para 91.

75 Law Commission, above n 2, para 88.

76 Law Commission, above n 2, para 88.

77 Liable concurrently with the entity, not instead of. Law Commission, above n 2, paras 89, 90.

78 Law Commission, above n 2, paras 89, 90, 101. 
2 The way in which those powers had been exercised up to the breach, ${ }^{79}$

79 Law Commission, above n 2, para 89. 
3 The respective moral blameworthiness of the Crown and the public body; ${ }^{80}$

4 The causative potency of the Crown's conduct and of the public body's conduct. ${ }^{81}$

The first factor, supervision and control, is substantially similar to that under the Public Finance Act 1989. If the Crown has devolved powers of supervision and control over Crown bodies, should it be able to plead this fact in order to avoid BORA liability? Policy considerations suggest that the answer is no. Factors 2, 3 and 4 point the court to an enquiry about relative degrees of fault. Did the Crown exercise its power in bad faith, or in a morally reprehensible way?

Any such extra requirements of fault, bad faith, or negligent conduct, despite going against the concept of strict liability, were also expressly rejected in the High Court case of Whithair $v$ Attorney-General. ${ }^{82}$ That case involved police action allegedly in breach of section 23 of the BORA. It was argued by the Crown that to constitute a breach of the BORA there had to be an element of conscious violation of, or reckless indifference to the plaintiff's rights under the BORA. If the facts were proved in Baigent, bad faith would have been established, therefore this issue was not directly dealt with in that case. The Chief Justice was adamant that no such additional element was required. The Chief Justice also stated that the damages available in the Baigent case were "described as a public law action directly against the State, as distinct from a private law action in the nature of a tort claim". ${ }^{83}$ It is significant that the Chief Justice contrasts the Baigent public law action with a private law tort action, where individual culpable conduct is required.

The High Court case of Hobson $v$ Harding 84 involved allegations by a doctor and patients of a BORA breach by Health Benefits Limited, the third defendant, an organisation set up by the four RHAs. The Northern Regional Health Authority was also a defendant. This case did not involve any fault by the Crown. Indeed there was no contributory Crown conduct. Nevertheless the Crown applied to have the AttorneyGeneral joined as a party to the proceedings and this was accepted as an appropriate action by the Court.

\footnotetext{
80 Law Commission, above n 2, para 89.

81 Law Commission, above n 2, paras 89, 106.

82 Above $n 59$.

83 Whithair above $\mathrm{n} 59,56$

84 Above $n 19$.
} 


\section{E Public Finance Act 1989}

In the Law Commission's report it is stated that it would be inappropriate to cut across the Public Finance Act 1989 by relieving public entities of legal and financial liability for their own breaches. ${ }^{85}$ And that: ${ }^{86}$

It would be inconsistent with the structure of Government worked out over our nation's history - especially in the last 10 years - for the Crown to have a general responsibility under the law to ensure that all who are subject to the Bill of Rights Act comply with it, and also have a correlative duty to pay monetary compensation for a breach ... If there is to be Crown responsibility, then there must, in general, be power to meet the responsibility as well.

Ten years ago the government had the power to meet those responsibilities, but the government's structure has since radically altered. The government has made deliberate decisions to devolve responsibility and control to various public entities. Central government has shrunk as a matter of government policy. Since 1989 governments have privatised 12 SOEs for a total sale price of $\$ 8.7$ billion. ${ }^{87}$ Should the Crown be able to devolve the BORA responsibility by privatisation or by the setting up separate legal entities without taking any responsibility?

The Law Commission stated that where there has been a devolution of operating authority and responsibility to a public body (eg a local authority or an SOE), that body is the appropriate defendant to a Baigent claim. ${ }^{88}$ The primary responsibility for the BORA breaches should follow the delegation of operating responsibilities. However, the matter is not that simple. First, because the BORA fulfils some of New Zealand's international obligations, liability under the Act is not like other legal liability that public entities face.

Second, the very point of the BORA is to act as a check on State power. If that responsibility can be devolved it ceases to function as a check. Therefore it cannot be assumed that it is delegated with other powers and responsibilities.

Third, although the government may have devolved authority to reduce risk, it should not be able to absolve itself of all responsibility. This is true even of SOEs. The 1996 briefing to the incoming SOE Minister ${ }^{89}$ specifically recognises that the government may wish to pursue social, employment and other non- commercial goals, as well as

85 Law Commission, above n 2, para 88.

86 Law Commission, above n 2, para 98. Emphasis added.

87 Briefing paper for the incoming Minister for State Owned Enterprises, CCMAU, 11 October 1996, 6.

89 Above $\mathrm{n} 87$. 
commercial or ownership goals, via SOEs. ${ }^{90}$ SOEs are still a key source of non-tax income and a possible tool for implementing government policy. ${ }^{91}$ Given this, the Crown cannot argue that actions of an SOE are nothing to do with it.

In relation to Crown entities, Allen Schick in his study of State sector reform noted that "even when the entity is independent, the Government still may be liable in case of negligence or default, and it may bear a political onus for perceived inadequacies in services". ${ }^{92}$ In fact, Schick states that one of the key effects of conferring Crown entity status is that the Government holds the public risk and the Crown entities spend the public money. An entity is able to gain the efficiencies of independent operation, but the Government is still ultimately responsible if the public money is ill-spent. The responsibility for how the taxpayer's money is used cannot be delegated away.

It is submitted that responsibility for New Zealand's international obligations cannot be delegated to Crown entities. Equally, responsibilities that are especially created to limit Crown activity, such as the BORA liability, cannot be delegated to Crown entities. If the Crown chooses to legislate for less supervision and control over public entities, and to decentralise many public functions, should it, by doing so, be able to absolve itself of responsibility for its international obligations? In principle, and in practice, it is not acceptable to make the entity liable in the first instance, without any Crown assistance or responsibility.

The practical effect of the Public Finance Act argument is that it provides a motivation for the Crown to decentralise and privatise further, because this will limit the Crown's liability under the BORA. Schick notes that "Crown entities lengthen the chain of accountability from policies made by Government at one end of the chain to the delivery of services at the other end". ${ }^{93}$ The longer the chain the less control the Crown has over the effective implementation and observance of human rights standards. As a consequence individuals may not be benefiting from the full measure of protections against the coercive power of the State that are available under the BORA, and by international obligations.

90 Above $\mathrm{n} 87,7-8$; see also an illuminating discussion by Keith $\mathrm{J}$ of the meaning of "public authority" which includes an analysis of the position of SOEs in NZ, in Commissioner of Inland Revenue $v$ Medical Council of New Zealand, above $\mathrm{n} 68$.

91 Shareholding Ministers may direct the Board of an SOE through the statement of corporate intent (s13 SOE Act) as to the objectives (s14(2)(a)), and nature and scope of activities to be undertaken (s14(2)(b)). While this method would rarely be used it is still an available tool.

92 A Schick The Spirit of Reform: Managing the New Zealand State Sector in a Time of Change A report prepared for the State Services Commission and the Treasury, August 1996, 38.

93 Schick, above n 92, 39. 
The situation is complicated by entities which have been fully privatised and then sold. ${ }^{94}$ This may completely remove them from the reach of the BORA liability. Given the wording of section 3 the entity will still be caught if its public function has remained the same but it is now operating as a private entity. Section 3 applies to entities exercising a public function. It is the nature of the function, not the body, which is the most appropriate test. ${ }^{95}$ For example, the privatising of the prisons would not be enough, in itself, to render the BORA inapplicable. ${ }^{96}$

\section{F Enforcing Remedies}

There is a practical difficulty with having the Crown as general guarantor that is highlighted by the Law Commission. ${ }^{97}$ If the Crown is the only party in an action and non-monetary relief is granted against a Crown entity, there may be difficulties enforcing that remedy. For example, a declaratory order against the Crown may be useless if the Crown has no control over the Crown entity in breach. As with strengthening incentives to comply with the BORA, if it is decided on principle that liability should lie with the Crown, enforcing remedies is a secondary issue. It should not affect the fundamental question of primary responsibility. The problem of enforcing remedies could be overcome if the Crown or the court has the power to join the culpable entity as a party if necessary, in order to grant a remedy against that entity. A position where the Crown is total guarantor does not preclude both the Crown and the entity being parties to proceedings. It merely means that the Crown interest is such, that it is always a party.

It is unlikely though, given the application of the BORA, that there will be many situations where the Crown does not have the requisite control to enforce a remedy. ${ }^{98}$ Most of the entities which fall within section 3(b) will be Crown entities. Even in situations where there is little or no express Crown power over an entity or private body, Parliament is far from powerless. Parliament can always pass legislation in order to ensure that an entity complies with a court order. Parliament has the power to do this in public and private cases.

94 For a discussion of BORA applicability to privatised entities see M Chen "Judicial Review of State Owned Enterprises at the Crossroads" (1994) 24 VUWLR 51.

95 See case law above $\mathrm{n} 68$. See also above $\mathrm{n}$ 67, 61 .

96 Above n 67, 61.

97 Law Commission, above n 2, para 96.

98 See Rights and Freedoms,, above n 35, 420-421. 
The Law Commission report highlights uncertainty over the appropriate defendant in BORA situations. This uncertainty in the law needs to be settled. The Law Commission's distinction is its proposed resolution of the issue. The distinction has several advantages including practicality, though there may also be some disadvantageous effects that counter the advantages gained.

\section{A Advantages}

\section{It makes sense}

The Law Commission's distinction makes sense. If the Crown did not contribute in any way to the breach why should it have to provide a remedy? The alleged victim will not be left without a remedy as she can sue the entity, which is actually responsible. If the entity cannot pay, the Crown will be a back-up. The distinction seems, on the face of it, to be "a most sensible proposal". 99 Crown entities should be responsible for the consequences of their acts.

It is useful to look at what lies behind the initial reaction that the Law Commission proposal makes sense. Partly it is that when thinking about liability fault is automatically considered relevant. It seems "unfair" to impose responsibility on the Crown for action in which it had no part. This is based on two questionable assumptions that have been discussed in Part IV, C above:

1 The Crown is like an individual and individuals are only responsible for liability to which their action contributed; and

2 The Crown is completely independent from Crown entities and therefore is not responsible in any way for their action.

The Law Commission's distinction also seems to make sense for another reason. The distinction is perfectly consistent with the way New Zealanders have come to view public entities - as accountable, as independent, and sometimes as limited liability companies operating for profit. The Government has moved to reduce its responsibility for previously key Crown areas such as heath and education by reducing Government funding, and Government control. The concept of Crown responsibility has diminished because of the government's actions over the past 10-12 years. This is part of the reason why the distinction "makes sense" in the current climate. The government is able to rely on a situation which it has itself created. Does the fact that the government has been able to narrow the concept of State responsibility over time mean that it can rely on that

99 "Baigent: An Update" R Best and P Radich [1997] NZLJ 209. For a different view see "Law Reform : Crown Liability and Judicial Activism" 20 TCL 19 (editorial, 27 May, 1997). 
concept, to justify bringing other areas into line with that narrow concept? Given the fundamental nature of the rights in the BORA, and its purpose, this may be a situation where it is appropriate to say that the government should state why it is legitimate to pass BORA liability on, as opposed to accepting the devolution of responsibility.

\section{It may strengthen incentives to comply}

A further advantage of the distinction is that it may strengthen the incentives of Crown entities to ensure that their processes and employees comply with the BORA. This is certainly a direct and probably effective way of providing incentives to comply, particularly for non-SOE Crown entities.

Imposing liability is less likely to create incentives for SOEs as their principal objective is to operate as successful businesses. ${ }^{100}$ It is unlikely that an SOE would change its processes in order to comply with the BORA if that significantly altered its competitiveness in the particular market in which it operated. While small changes would be effected easily, the profit motive would always limit the scale of changes that could be made to ensure compliance with the BORA.

Other Crown entities may not have the resources to make any substantial changes to ensure compliance. For example, boards of trustees may decide that they do not have sufficient funds to undertake any significant BORA review and implementation process, and that the best option is to risk a breach. In terms of the other Crown entities ${ }^{101}$ the incentives to comply could be more effective as they may not be under the degree of pressure for resources felt by boards of trustees.

\section{Limiting Crown liability}

If a fear of a burgeoning Baigent liability is a compelling consideration ${ }^{102}$ then the Law Commission's distinction will serve to limit Crown liability. By restricting Crown liability to the executive under section 3(a) the Crown's liability would be limited to actions against the police, Government departments and Ministers. Given that BORA liability has become increasingly diverse, moving away from actions against the police, this proposal would significantly contain the costs directly attributable to Baigent liability.

100 Section 4, SOE Act 1986.

101 Fourth Schedule, Public Finance Act 1989.

102 See for example A Butler "The New Zealand Bill of Rights Act and Private Common Law Litigation" [1991] NZLJ 261. 


\section{B Disadvantages}

Assuming that the Law Commission's proposal is implemented, including the provision providing for Crown residual liability, there are a number of possible disadvantages.

\section{Potential breach of international obligations}

Implementation of the Law Commission's proposal is more likely to leave New Zealand in breach of its international obligations. It is a higher risk option. Allen Schick notes that the Crown entities are a diverse group that are not homogeneous in either form or function. ${ }^{103}$ Of 2,700 different Crown entities (excluding SOEs) 2,600 are school Boards of Trustees. It is unlikely that these Crown entities, particularly school Boards, are in any position to fulfil the Crown's international obligations by protecting the wide range of fundamental rights contained in the BORA. Processes, structures and resources need to be provided by the Crown to ensure that these rights are protected. This would require that the Crown acknowledge the interest and responsibility it has in this area.

Without State intervention most schools do not have the resources or the expertise to ensure that they are safeguarding BORA rights to an adequate level. The same may be true of other Crown entities which are struggling with limited resources, for example Crown Health Enterprises (CHEs), Crown Research Institutes (CRIs), Maori Language Commission. As noted SOEs are in a different position because their principal objective is to pursue profit. It is likely that this objective would significantly curtail any efforts to fulfil BORA obligations. The end result may be a significant increase in breaches of the BORA by Crown entities and SOEs. Although the residual Crown liability provision may ensure that those breaches are remedied, that is very different from ensuring that breaches of the BORA do not occur, or that BORA breaches are substantially reduced in number.

The trend is for international law to impact increasingly in the domestic sphere. ${ }^{104}$ Any State action which gives up control and responsibility severely reduces the State's

103 Above n 92, 37.

104 M Kirby "The Impact of International Human Rights Norms: A Law Undergoing Evolution" (1995) 25 Western Australia Law Review 30; J Terry "Thinking Globally: Using International Law to Buttress Bill of Rights Act Arguments" [1997] BRB 2; Report of the Judicial Colloquium on the Domestic Application of International Human Rights Norms, Bangalore, India: Chairman's Concluding Statement "Bangalore Principles" 26 February 1988; Vienna Declaration and Programme of Action (1993) arts 1, 5, UNDoc A/49/668, adopted UNGA Resolution 48/121, December 20, 1993, 14 HRLJ 352 (1993), 32 ILM 1661 (1993); P Hunt and Prof Bedggood "The International Law Dimension of Human Rights in New Zealand" Chpt 2 in Rights and Freedoms above $\mathrm{n} 36$. 
ability to respond to its international obligations. The 1996 Briefing to the incoming Justice Minister notes that: ${ }^{105}$

As domestic practice and international law become further entwined, Government policy and practice are increasingly liable to be tested against international standards. To maintain accountability, Government and its advisers need to be fully conversant with international developments and vigilant about compliance with existing obligations.

By handing responsibility for BORA liability over to Crown entities and SOEs the Crown is reducing its control over compliance with those obligations by Crown entities. In June 1995 New Zealand made its third report to the United Nations Human Rights Committee on implementation of the ICCPR. ${ }^{106}$ Under the heading "Principal Subjects of Concern," the UN Human Rights Committee expressed concern about the absence of express provision for remedies for all those whose rights under the Covenant or the BORA have been violated. ${ }^{107}$ This comment was made notwithstanding the fact that Baigent had been decided prior to submission of the report and was brought to the attention of the Committee. ${ }^{108}$ This reflects the high degree of importance the Committee places on the provision of remedies in relation to ICCPR obligations.

In order to address this concern the Crown should be looking to widen, and make more explicit, the remedies available for BORA breaches. The Law Commission's distinction would make the law explicit on the appropriate avenue for a remedy but will leave gaps in the coverage in relation to section 3(a), and narrows the Crown's liability.

The Law Commission's response to the Human Rights Committee's expressions of concern was to assert that all that international law requires is that an effective remedy be available. ${ }^{109}$ The way in which that remedy is made available is not the Committee's concern. ${ }^{110}$ Rather, it is the State's own business. The defensive position taken by the Law Commission towards the Human Rights Committee is in contrast to the fact that New Zealand has ratified, and partially implemented the ICCPR ${ }^{111}$ including, and in

105 Briefing paper for the incoming Minister of Justice, October 1996, 44.

106 Under article 40(1) of the ICCPR.

107 "Human Rights in New Zealand" Report to the United Nations Human Rights Committee under the ICCPR, MFAT Information Bulletin Number 54, June 1995, 69.

108 Above n 107, 36, 39; see also Law Commission, above n 2, para 81 where this is noted by the Commission.

109 Article 2(3), ICCPR.

110 Law Commission, above n 2, para 83.

111 Some key articles of the ICCPR are left out of the BORA. For example art 3, equal rights of men and women; art 8, no slavery or forced labour; art 11, no imprisonment for inability of fulfil a 
particular, the Optional Protocol. ${ }^{112}$ The Human Rights Committee is the authoritative, independent tribunal whose only job is to rule and comment on whether States are acting in accordance with the ICCPR. ${ }^{113}$ It is too late for New Zealand to assert that what it does in the domestic sphere in relation to the ICCPR is beyond the reach of this Committee. New Zealand gave up that right when it submitted to the Committee's jurisdiction.

If Crown residual liability is accepted as part of the Law Commission's proposal, then the international law requirement of providing an effective remedy will be substantially complied with. The residual liability provision does provide a mechanism by which most plaintiffs can obtain an effective remedy. It is submitted though, that the Law Commission's proposal still involves a substantially high risk of breach by New Zealand of its international obligations. These obligations require State action to avoid breaches of rights, not merely to remedy breaches once they occur.

\section{Residual Crown liability in practice}

The provision of residual Crown liability under the Law Commission's proposal is a crucial part of ensuring that New Zealand does not flagrantly breach its international obligations by failing to provide a remedy for all BORA violations. Yet the provision of Crown residual liability may have practical effects that off-set any reduction in Crown primary liability.

If the Law Commission's proposal is implemented, presumably Crown entities will assume liability from a certain date for all BORA breaches. They may be told that this means that if they act in contravention of the BORA they may be liable for damages or any other appropriate remedy. If a plaintiff is awarded a damages remedy against the entity and the entity cannot meet that award the Crown is residually liable. In those circumstances the court can direct the Crown to provide appropriate redress.

It is possible that the Crown entity's reaction may mean that with the residual liability proposal the Crown gets the worst of both worlds. A board of trustees for example has no incentive to put money aside to make provision for BORA breaches as the Crown will pay if the Board cannot. In the unlikely situation that BORA cases increase significantly in number it may motivate profligate, even irresponsible, spending by Boards and other

contractual obligation; art 16, right to legal personality; art 23, protection of the family and the right to marry freely; art 24, rights of the child. For commentary see J Elkind and A Shaw $A$ Standard for Justice (Oxford University Press, Auckland, 1986).

112 Above $\mathrm{n} 8$.

113 In this vein see JS Davidson "The Procedure and Practice of the Human Rights Committee under the First Optional Protocol to the ICCPR" [1991] 4 Canterbury Law Review 337. 
public entities to ensure that their money is always spent on their "core" business, and that they are too poor to meet a $\$ 15,000^{114}$ - $\$ 70,000^{115}$ BORA award.

In order to minimise these effects the Crown may choose to force each entity to have a BORA contingency fund that would be available to meet potential awards. The first problem is that forcing entities to have such a fund defeats the purpose of devolution and decentralisation. Devolution and decentralisation are meant to move decision-making about costs and spending to lower levels. Local decision-makers, it is argued, have access to more accurate and current information and are able to make more appropriate decisions. ${ }^{116}$ In theory this means that resources are used more efficiently. A centralised decision that entities will allocate money to a BORA contingency fund is contrary to these principles.

The second problem is that forcing all Crown entities to have such a fund would be extremely inefficient, and would tie up a large amount of money unnecessarily because only a small number of public entities will ever be the subject of BORA damages awards. ${ }^{117}$

\section{Litigating Bill of Rights Act breaches}

By delegating primary liability to the public entities the Crown is not involved in the litigation process. The Crown is not then able to influence that process when a public entity is involved. The Crown cannot provide competent counsel, put certain arguments to the courts in relation to the BORA, or decide to settle. Yet ultimately the Crown may have to pay the award. A board of trustees may not be able to hire a lawyer conversant with BORA issues, or may pursue a case that should have been settled for $\$ 20,000$, resulting in an award of $\$ 50,000$ for which the Crown has to assume liability.

The Crown may be better off being involved from the start and having some control over the process. In particular, a centre of expertise in BORA actions could be built up by the Crown's lawyers. Crown Law Office counsel, for example, could direct legal argument in order to direct BORA jurisprudence in the interests of the public. Ultimately it is the judiciary which will interpret the BORA, drawing on domestic and international

114 Upton $v$ Green above $\mathrm{n} 59$ - award was $\$ 15,000$ for loss of a chance. See Law Commission, above $\mathrm{n}$ 2, para 68.

115 As per Cooke P in Baigent, above n 1, 678. See also Law Commission, above n 2, para 71.

116 See John Martin "Revolution and Decentralisation" chapter 10 in Reshaping the State: New Zealand's Bureaucratic Revolution edited by J Boston, J Martin, J Pallot and P Walsh (OUP, Auckland 1991) 268.

117 As opposed to the much larger number that are subject to BORA claims. See Law Commission, above n 2, Appendix A. 
material, although the Crown is in a unique position to be able to make arguments on the range of possible interpretations of these rights incorporating overseas precedent. This opportunity for shaping interpretation arises as there are still key rights in the BORA that have to be interpreted. ${ }^{118}$ Increased quality of argument benefits not only the party to the proceedings but also those who subsequently rely on the cases. ${ }^{119}$ The Law Commission did address this in part by suggesting that the Attorney-General be served with all BORA proceedings and have the right to apply to be made a party and to be heard, whether or not there is potential liability of the Crown. ${ }^{120}$

\section{CONCLUSION}

Baigent's case highlighted primary liability as an issue. The Law Commission proposed primary liability on the entity in breach because the entity is the most appropriate defendant. The interests of the Crown are recognised by allowing the Attorney-General to apply to make submissions to the Court, or to be made a party. The interests of the victim are protected, if necessary, by residual Crown liability. What is not discussed or resolved in the Law Commission's report is the nature of the Crown's interest in BORA cases. Arguably this is the starting point for addressing issues of liability.

This article has analysed the Law Commission's proposal in relation to the Crown's responsibility for Baigent liability. Given that a purpose of the BORA is to provide a check on the power of the State, it is prudent to apply a strict analysis to any proposal by the State to narrow its liability or to restrict the effectiveness of BORA measures in any way.

This article has looked at the justifications for the Law Commission's proposal, as well as some possible disadvantages and practical effects. The proposal does make the law certain on the appropriate avenue for a remedy. The proposal narrows the Crown's liability as well as leaving gaps in the coverage. Given the increasing significance of international obligations the Crown should be looking to widen and make more explicit the remedies available for BORA breaches. Thus, the Law Commission's proposal is not the route that New Zealand's BORA jurisprudence should be following.

It is outside the scope of this article to put forward an alternative proposal but an alternative can, at least, be suggested. At the other end of the spectrum, from the Law Commission's proposals is the possibility of the Crown as total guarantor. Under this

118 For example s 20, rights of minorities; s 27, right to justice.

119 Above n 35, 158

120 Law Commission, above n 2, para 73. 
option the Crown would always be the appropriate defendant to a BORA action, which is an action in public law against the State. The Crown could recover the money from the entity in breach by internal mechanisms, if it so wished.

This article has argued for Crown responsibility but that does not necessarily mean Crown liability. The best solution may lie somewhere between the two options. In a BORA action there could be concurrent liability. In those section 3(b) cases where a separate Crown entity is involved the Crown would always be a party because of the Crown's high degree of interest in BORA actions coupled with its responsibility for securing an acceptable outcome for the victim. The entity in breach would also be a party to the proceedings. Finding a just and appropriate solution is the most important consideration. This would provide certainty in the law. Preferably any solution should also preserve the integrity of the BORA jurisprudence thus far. ${ }^{121}$

The Bill of Rights Act 1990 deals with human rights, reflections of society's choice of moral vision and the minimum requirements of a life of dignity. ${ }^{122}$ This is no small matter. No government can afford to downplay the significance of human rights: "Human rights are a standard of political legitimacy; to the extent that governments protect human rights, they and their practices are legitimate."123

121 Though this does not seem to have happened in other BORA areas - in particular the area of search and seizure, s21. The Court of Appeal cases of $R v$ Grayson and Taylor (1996) 3 HRNZ 250 and $R v$ Fraser [1997] 2 NZLR 442, reversed earlier CA authorities on s21 without distinguishing them or giving reasons. See S Optican "Rolling Back s21 of the Bill of Rights" [1997] NZLJ 42.

122 J Donnelly Universal Human Rights in Theory and Practice (Cornell University Press, Ithaca, 1989) 17.

123 Above n 122, 14. 
